\title{
Serum Vitamin D Level in Children with and without Type 1 Diabetes Mellitus
}

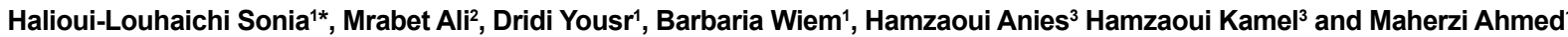

${ }^{1}$ Pediatric Department of Mongi Slim Hospital La Marsa, Medicine Faculty of Tunis, University of Tunis El Manar, Tunisia

${ }^{2}$ Military Center of Hygiene and Protection of the Environment, Medicine Faculty of Tunis, University of Tunis El Manar, Tunisia

${ }^{3}$ University of Tunis El Manar, Medicine Faculty of Tunis, Homeostasis and Cell Dysfunction Unit Research, 15 Djebel Lakhdhar Street 1007 , Tunis, Tunisia

\section{Abstract}

For years, vitamin $\mathrm{D}$ has been associated to many immune disorders. Several studies have shown association between low serum $25 \mathrm{OH}$ vitamin $\mathrm{D}$ and type 1 diabetes mellitus (T1DM).

Objective: To compare 25 hydroxy vitamin D (25 OHD) level in T1DM patients to non-diabetic children hospitalized or seen in emergency for other diseases at the same period.

Methods: It was a case-control study including 29 patients with T1DM and 28 non - diabetic control children They were comparable in age, gender, weight, length, BMI and season of blood sampling. Epidemiological and clinical data were collected and $25 \mathrm{OHD}$ serum level was measured with a radioimmunoassay kit.

Results: $25 \mathrm{OHD}$ level was significantly lower in diabetic patients (mean: $19.62 \mathrm{ng} / \mathrm{ml}$, range $15-26 \mathrm{ng} / \mathrm{ml}$ ) than in control patients $(24.64 \mathrm{ng} / \mathrm{ml}, 20-28 \mathrm{ng} / \mathrm{ml}), p=0.00$. All participants (T1DM patients and controls) had inadequate levels of vitamin $\mathrm{D}$.

Conclusion: Children with T1DM have lower vitamin D levels than control group.

Keywords: Vitamin D; Deficiency; Type 1 diabetes mellitus; Children

\section{Introduction}

Type 1 diabetes mellitus (T1DM) is an auto immune disease with contribution of environmental factors in its causation. In susceptible persons, cytokine production and lymphocyte proliferation have been postulated to be decreased by immunomodulatory actions of vitamin D [1]. For years, interest in diabetes mellitus and vitamin D metabolism has grown. Many epidemiological studies have found high prevalence of vitamin $\mathrm{D}$ deficiency in children with type 1 diabetes mellitus, suggesting a strong relationship between the two [2,3]. It is hypothesized that vitamin D may have a therapeutic role in T1DM via its immune-modulatory properties [4].

To the best of our knowledge, there are no population-based studies that have examined the association between vitamin D and T1DM in Tunisian children.

The purpose of our study is to measure vitamin D levels in young children withT1DM and to compare them with levels in non- diabetic subjects at the same period.

\section{Methodology}

\section{Subjects}

We proceeded to a case control study performed in the department of pediatrics of Mongi Slim hospital in Marsa, Tunisia, from June 2014 to June 2015. The study included 29 children diagnosed as T1DM on the basis of the American diabetes society criteria (symptoms of diabetes and casual plasma glucose $\geq 7.0 \mathrm{mmol} / \mathrm{L}$ or a 2 -h post load glucose concentration $\geq 11.1 \mathrm{mmol} / \mathrm{L}$ during an oral glucose tolerance test) [5] and without any medical comorbidities or any other chronic disease. This sample included youth with recently diagnosed T1DM and youth with established T1DM. Age of patients ranged from 7 months to 14 years. As control group, 28 children randomly recruted from emergency or admitted to hospital in the same period were studied. All did not report any chronic or auto immune disease. Participants and their families then completed a set of questionnaires and youth provided a blood sample for analysis. They were comparable in age, gender, weight, length, BMI and season of blood sampling. We categorized each participant's blood sample according to the follow division of the calendar year: spring (1 March-31 May), summer (1 June-31 August), fall (1 september-30 November), winter (1 december-28 February)

\section{Serum $25(\mathrm{OH})$ D levels}

The standard indicator of vitamin $\mathrm{D}$ status is serum 25-hydroxyvitamin D (25OHD) which is composed of cholecaciferol (vitamin D3) and ergocalciferol (vitamin D2). Serum concentrations of $25(\mathrm{OH}) \mathrm{D}$ were measured with a radioimmunoassay kit that detects the both forms [6]. In our study, concentrations of vitamin D were measured by a radioimmunoassay Kit (Dia-Sorin, Stillwater, MN, USA) and performed using ELISA technique. The collected serum was immediately shaded from direct light and stored at $-20^{\circ} \mathrm{C}$. All samples were analyzed simultaneously at the same laboratory, using the same technique conducted by one technician. Level values were reported in nanograms per milliliter. In descriptive analysis, vitamin D levels were categorized as sufficient $(\geq 30 \mathrm{ng} / \mathrm{ml})$, insufficient $(\geq 20 \mathrm{ng} / \mathrm{ml}$ and $<30 \mathrm{ng} / \mathrm{ml})$ and deficient $(<20 \mathrm{ng} / \mathrm{ml})$ on the basis of previous recommendations [7].

*Corresponding author: Dr. Halioui-Louhaichi Sonia, Pediatric Department of Mongi Slim Hospital La Marsa, Tel: 0021622130024; E-mail: Sonia.halioui@rns.tn

Received February 09, 2016; Accepted March 07, 2016; Published March 13, 2016

Citation: Sonia HL, Ali M, Yousr D, Wiem B, Anies H, et al. (2016) Serum Vitamin $\mathrm{D}$ Level in Children with and without Type 1 Diabetes Mellitus. J Diabetes Metab 7 655. doi:10.4172/2155-6156.1000655

Copyright: ( 2016 Sonia HL, et al. This is an open-access article distributed unde the terms of the Creative Commons Attribution License, which permits unrestricted use, distribution, and reproduction in any medium, provided the original author and source are credited. 
Citation: Sonia HL, Ali M, Yousr D, Wiem B, Anies H, et al. (2016) Serum Vitamin D Level in Children with and without Type 1 Diabetes Mellitus. J Diabetes Metab 7: 655. doi:10.4172/2155-6156.1000655

Page 2 of 4

\section{Ethics}

Informed parental consent was obtained to be eligible for enrollment into the study. It was done according to the rules of the local ethics committee of our hospital.

\section{Statistical analysis}

Values for all parameters, expect gender and season of blood sampling, were expressed as mean \pm SD. Two-tailed unpaired Student's $t$ test was used for comparison of normally distributed variables (with the Mann-Whitney U test for skewed data), and the Chi2 test for categorical variables (with the Fisher exact test for skewed data). A P value $<0.05$ defined the level of statistical significance. Data analysis was performed using the SPSS 15.0 statistical software package.

\section{Results}

Mean disease duration in our study was $35.03 \pm 42.4$ months (range $=0-168$ ) with 7 newly diagnosed cases. The control group and the diabetic one were comparable as regards age, gender, weight, length, BMI, or season of blood sampling respectively (Table 1).

In this study, we found that all participants had inadequate levels of vitamin D. Serum 25OHD in children with T1DM as a group (established and newly diagnosed T1DM combined) was significantly lower compared to control children (Figure 1).

15 diabetics $(51.7 \%)$ were deficient $(17.4 \pm 1 \mathrm{ng} / \mathrm{ml}) .14$ diabetics were insufficient $(21.9 \pm 2 \mathrm{ng} / \mathrm{ml})$, meanwhile all controls were insufficient ( $\mathrm{p}<0.001 ; \mathrm{OR}=3$ IC 95\%:1.95-4.60) (Figure 2). No difference in vitamin $\mathrm{D}$ level between newly diagnosed diabetics and those with established T1DM.

In bivariate analysis, age, gender, $\mathrm{BMI}$, duration of T1DM, season of blood sampling, insulin requirements and $\mathrm{HbA1C}$ level were similar among diabetic patients with vitamin D deficiency and insufficiency (Table 2).

\section{Discussion}

Our study showed that vitamin D level was considerably lower in T1DM patients compared with non-diabetic children. A significant difference in the mean value of vitamin $\mathrm{D}$ between the two groups was found $(p=0.00)$. It confirms previous results of other studies in T1DM children that showed that serum 25 OHD was lower in T1DM patients than in control group [8-12]. However, in these studies, controls were healthy subjects, while in our study controls were children admitted to hospital or seen in emergency for other reasons and thus expected to have lower serum 25 OHD than healthy children supporting the role of vitamin D in defense mechanism [13]. In fact, low vitamin D level has been reported in both acute and chronic diseases [14,15]. It was implicated in cardiovascular diseases [16], kidney disease [17], asthma [18], multiple sclerosis [19], rheumatoid arthritis [20], several malignancies [21] and immune disorders [22].

Although our use of hospital controls, serum 25 OHD in diabetic subjects was significantly lower and this is strength of our study supporting the potential role of vitamin $\mathrm{D}$ in the development of auto immune diseases as it was reported by Bruna et al. [23].

Because vitamin D status is linked to exposure to sunlight, we examined 25 OHD levels as a function of season of blood sampling. In Switzerland, vitamin D deficiency rose to $84.1 \%$ in winter in T1DM children [3], which shows season as an important contributor to vitamin D status. However, in our study, we did not observe significant difference while comparing 25OHD levels among the study groups through the four seasons.

On the other hand, in the present study, all participants had inadequate level of vitamin $\mathrm{D}$ despite Tunisia is a solar rich country. These findings implicate that vitamin D deficiency may be seen even in children without any auto immune or chronic disease. This agreed with a study performed in Egypt who revealed that both T1DM and controls were vitamin $\mathrm{D}$ insufficient however serum vitamin $\mathrm{D}$ levels were not

\begin{tabular}{|l|c|c|c|c|}
\hline Covariate & Levels & T1DM & Controls & P value \\
\hline $\begin{array}{l}\text { Age, months } \\
\text { mean } \pm \text { SD } \\
\text { Range }\end{array}$ & $\begin{array}{c}106.3 \pm 47.7 \\
{[7-182]}\end{array}$ & $\begin{array}{c}107.5 \pm 51.3 \\
{[20-182]}\end{array}$ & $\begin{array}{c}105.1 \pm 45.9 \\
{[76180]}\end{array}$ & 0.89 \\
\hline Gender & $\mathrm{F}$ & $\begin{array}{c}15(51.7 \%) \\
14(48.3 \%)\end{array}$ & $\begin{array}{c}15(53.6 \%) \\
13(46.4 \%)\end{array}$ & 0.55 \\
\hline $\begin{array}{l}\text { Weight } \\
\text { Mean } \pm \text { SD } \\
\text { Range }\end{array}$ & $\mathrm{Kg}$ & $\begin{array}{c}32.8 \pm 14.7 \\
{[10-65]}\end{array}$ & $\begin{array}{c}27.8 \pm 15.5 \\
{[14-75]}\end{array}$ & 0.21 \\
\hline $\begin{array}{l}\text { Length } \\
\text { Mean } \pm \text { SD } \\
\text { Range }\end{array}$ & $\mathrm{cm}$ & $\begin{array}{c}132.9 \pm 27.5 \\
{[74-186]}\end{array}$ & $\begin{array}{c}124.6 \pm 21.7 \\
{[91-169]}\end{array}$ & 0.21 \\
\hline $\begin{array}{l}\text { BMI Mean } \pm \text { SD } \\
\text { Range }\end{array}$ & $\mathrm{kg} / \mathrm{m}^{2}$ & $18.15 \pm 3.80$ & $17.42 \pm 4.24$ & 0.49 \\
\hline \multirow{2}{*}{$\begin{array}{l}\text { Season of } \\
\text { blood sampling }\end{array}$} & Summer & $14.56-32.87]$ & {$[7.63-26.25]$} & $0.4 \%)$ \\
\cline { 2 - 5 } & Winter & $7(24.1 \%)$ & $0(0 \%)$ & 0.50 \\
\cline { 2 - 6 } & Fring & $9(31.1 \%)$ & $10(35.7 \%)$ & 0.67 \\
\hline
\end{tabular}

Table 1: Characteristics of studied population.

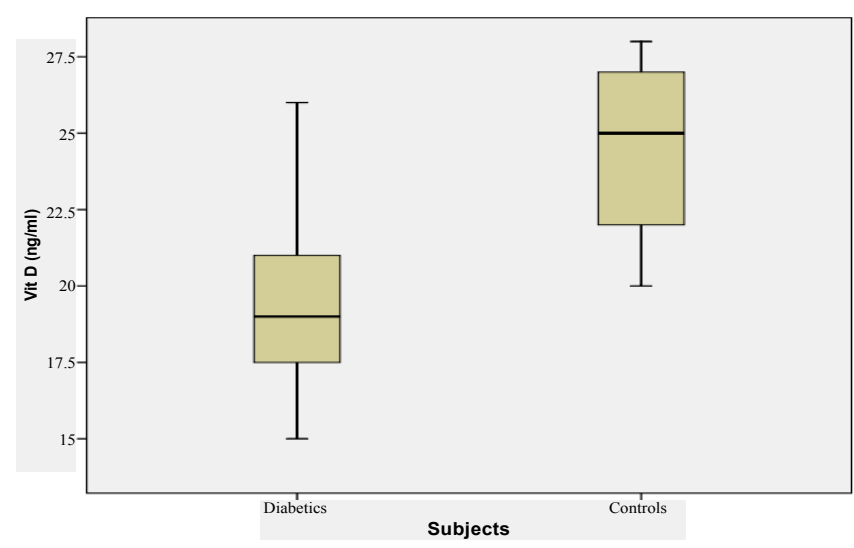

Figure 1: Comparison of vitamin D levels between diabetics and controls.

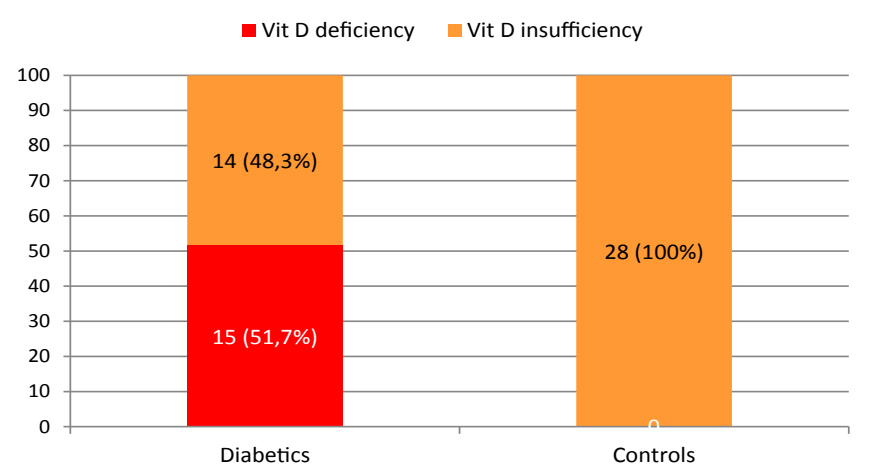

Figure 2: Class of vitamin $D$ in diabetics an controls. 


\begin{tabular}{|c|c|c|c|c|}
\hline & $\begin{array}{c}\text { Total sample } \\
\mathrm{N}=\mathbf{2 9}\end{array}$ & $\begin{array}{c}\text { Vit D } \\
\text { insufficient } \\
n=14(48.3 \%)\end{array}$ & $\begin{array}{l}\text { Vit } \mathrm{D} \text { deficient } \\
\mathrm{n}=15(51.7 \%)\end{array}$ & $P$ value \\
\hline $\begin{array}{l}\text { Age, months } \\
\text { Mean } \pm \text { SD } \\
\text { Range }\end{array}$ & $\begin{array}{c}106.3 \pm 47.7 \\
{[7-182]}\end{array}$ & $\begin{array}{c}107.5 \pm 51.3 \\
{[20-182]}\end{array}$ & $\begin{array}{c}105.1 \pm 45.9 \\
{[76180]}\end{array}$ & 0.89 \\
\hline $\begin{array}{l}\text { Gender } \\
\text { F } \\
\text { M }\end{array}$ & $\begin{array}{l}15(51.7 \%) \\
14(48.3 \%)\end{array}$ & $\begin{array}{c}9(60 \%) \\
5(35.7 \%)\end{array}$ & $\begin{array}{c}6(40 \%) \\
9(64.3 \%)\end{array}$ & 0.17 \\
\hline $\begin{array}{l}\mathrm{BMI}, \mathrm{kg} / \mathrm{m}^{2} \\
\text { mean } \pm \mathrm{SD} \\
\text { Range }\end{array}$ & $\begin{array}{c}18.15 \pm 3.80 \\
{[14.5-32.8]}\end{array}$ & $\begin{array}{c}18.68 \pm 4.72 \\
{[14.96-32.87]}\end{array}$ & $\begin{array}{c}17.58 \pm 2.54 \\
{[14.56-21.08]}\end{array}$ & 0.44 \\
\hline $\begin{array}{l}\text { Duration of T1DM } \\
\text { mean } \pm \text { SD } \\
\text { Range }\end{array}$ & $\begin{array}{c}35 \pm 42.3 \\
{[0-168]}\end{array}$ & $\begin{array}{c}38.3 \pm 52.3 \\
{[0-168]}\end{array}$ & $\begin{array}{l}32 \pm 32 \\
{[0-102]}\end{array}$ & 0.69 \\
\hline $\begin{array}{l}\text { Season of blood } \\
\text { sampling } \\
\text { Summer } \\
\text { Winter } \\
\text { Spring } \\
\text { Fall }\end{array}$ & $\begin{array}{c}1(3.4 \%) \\
7(24.1 \%) \\
9(31.1 \%) \\
12(41.4 \%)\end{array}$ & $\begin{array}{c}0(0 \%) \\
3(21.4 \%) \\
5(35.7 \%) \\
6(42.8 \%)\end{array}$ & $\begin{array}{c}1(6.6 \%) \\
4(26.6 \%) \\
4(26.6 \%) \\
6(40 \%)\end{array}$ & $\begin{array}{l}0.51 \\
0.54 \\
0.44 \\
0.87\end{array}$ \\
\hline $\begin{array}{l}\mathrm{Hb} \text { A1C (\%) } \\
\text { mean } \pm \text { SD } \\
\text { Range }\end{array}$ & $\begin{array}{c}10.30 \pm 1.9 \\
{[6.5-14]}\end{array}$ & $\begin{array}{c}10.02 \pm 1.6 \\
{[7.1-14]}\end{array}$ & $\begin{array}{c}11.17 \pm 2.2 \\
{[6.5-14]}\end{array}$ & 0.13 \\
\hline $\begin{array}{l}\text { Insulin } \\
\text { requirements UI/Kg } \\
\text { mean } \pm \text { SD } \\
\text { Range }\end{array}$ & $\begin{array}{l}0.93 \pm 0.2 \\
{[0.55-1.7]}\end{array}$ & $\begin{array}{l}0.91 \pm 0.1 \\
{[0.64-1.2]}\end{array}$ & $\begin{array}{l}0.97 \pm 0.3 \\
{[0.55-1.7]}\end{array}$ & 0.59 \\
\hline $\begin{array}{l}25 \mathrm{OHD} \\
\text { mean } \pm \text { SD } \\
\text { Range }\end{array}$ & $\begin{array}{c}19.62 \pm 2.7 \\
{[15-26]}\end{array}$ & $\begin{array}{c}21.9 \pm 2 \\
{[20-26]}\end{array}$ & $\begin{array}{l}17.4 \pm 1 \\
{[15-19]}\end{array}$ & 0.00 \\
\hline
\end{tabular}

Table 2: Characteristics of T1DM participants.

significantly lower in diabetic subjects compared to the control group $(24.7 \pm 5.6$ vs. $26.5 \pm 4.8 \mathrm{ng} / \mathrm{ml} ; \mathrm{p}>0.05)$ [24]. It could be due to the lack of comparability between the two groups. They were only suitable for age and gender. Other parameters have not been studied.

In our study, no significant difference between vitamin $\mathrm{D}$ deficient diabetic patients and those with vitamin $\mathrm{D}$ insufficiency regarding age, gender, BMI, duration of T1DM. These results are discordant with other studies. Nesibe Andiran et al. [25] found that vitamin D deficiency was higher in girls than in boys, especially in the adolescent age group. This may be due to the clothing habits in Turkish girls. It was also noted that the frequency of vitamin D deficiency increased with age [25] and that it was more prevalent among overweight and obese people $[26,27]$. The ethiopathogenesis of vitamin D deficiency in obese people is not clear. It is suggested that the sequestration of vitamin $\mathrm{D}$ in the subcutaneous body fat reduced its bioavailability [28].

Our data did not also show any difference in HbA1C levels and insulin requirements in vitamin $\mathrm{D}$ deficient or insufficient patients. We are so not in line with Sgragg et al. [29] and Hypponen et al. [30] who found that serum 25 OHD levels were inversely correlated with $\mathrm{Hb} \mathrm{AlC}$ independent of body fat, implying higher ambient glucose concentrations in children with lower vitamin D concentrations. In our study, the small sample size was one of our limitations. We believe that more studies and even multicenter approaches may be necessary to attain larger sample sizes and to better investigate the correlations.

There are some explanations for the relationship between T1DM and low levels of vitamin D. T1DM is an auto immune disease occurring in the pancreatic cells, and vitamin $\mathrm{D}$ is now widely known to play an immunomodulatory role through the vitamin $\mathrm{D}$ receptor present in pancreatic and immune cells. In fact, in animal models (mostly NOD mouse), it have been shown that high doses of 1,25 di-hydroxy vitamin
D successfully reduce the incidence of diabetes by decreasing the number of effector $\mathrm{T}$ cells, inducing $\mathrm{T}$ reg cells and reducing chemokine production by islet cells [31]. In vivo, it has been reported that 1, 25 dihydroxy vitamin $\mathrm{D}$ inhibits the expression of inflammatory cytokines in monocytes, such as IL 6, TNF alpha and IL12 in normal individuals. The influence of vitamin $\mathrm{D}$ on cytokine production by lymphocytes may be another important link between immune system and $25 \mathrm{OHD}$ [32]. Also, it has been proved that vitamin D supplementation in mice prevents the onset of diabetes [33]. Furthermore, it have been suggested that supplementation with vitamin $\mathrm{D}$ during pregnancy and early childhood may reduce the risk of early onset T1DM by $80 \%$ [34], and perhaps, even after the onset of diabetes, it may improve glycemic control [35].

In conclusion, vitamin D deficiency and insufficiency were found in Tunisian children with and without T1DM. It seems that vitamin D supplementation should be provided for both auto immune and other diseases.

\section{Conclusion}

This study revealed that vitamin $\mathrm{D}$ level in diabetic subjects is significantly lower than non-diabetic patients. However, even control patients were vitamin $\mathrm{D}$ insufficient despite the high sunlight exposure of our country. It will be of interest to future studies to investigate in vitamin $\mathrm{D}$ supplementation for auto immune diseases particularly T1DM.

\section{References}

1. Acharjee S, Ghosh B, Al-Dhubiab BE, Nair AB (2013) Understanding type 1 diabetes: etiology and models. Can J Diabetes 37: 269-276.

2. Mathieu C, Gysemans C, Giulietti A, Bouillon R (2005) Vitamin D and diabetes Diabetologia 48: 1247-1257.

3. Janner M, Ballinari P, Mullis PE, Flück CE (2010) High prevalence of vitamin D deficiency in children and adolescents with type 1 diabetes. Swiss Med Wkly 140: w13091.

4. Wolden-Kirk H, Overbergh L, Christesen HT, Brusgaard K, Mathieu C (2011) Vitamin $D$ and diabetes: its importance for beta cell and immune function. Mo Cell Endocrinol 347: 106-120.

5. Expert Committee on the Diagnosis and Classification of Diabetes Mellitus (2003) Report of the expert committee on the diagnosis and classification of diabetes mellitus. Diabetes Care 26 Suppl 1: S5-20.

6. Hollis BW, Napoli JL (1985) Improved radioimmunoassay for vitamin D and its use in assessing vitamin D status. Clin Chem 31: 1815-1819.

7. Holick MF (2006) High prevalence of vitamin D inadequacy and implications for health. Mayo Clin Proc 81: 353-373.

8. Daga RA, Laway BA, Shah ZA, Mir SA, Kotwal SK, et al. (2012) High prevalence of vitamin $D$ deficiency among newly diagnosed youth-onset diabetes mellitus in north India. Arq Bras Endocrinol Metabol 56: 423-428.

9. Bierschenk L, Alexander J, Wasserfall C, Haller M, Schatz D, et al. (2009) Vitamin $D$ levels in subjects with and without type 1 diabetes residing in a solar rich environment. Diabetes Care 32: 1977-1979.

10. Bener A, Alsaied A, Al-Ali M, Al-Kubaisi A, Basha B, et al. (2009) High prevalence of vitamin $D$ deficiency in type 1 diabetes mellitus and healthy children. Acta Diabetol 46: 183-189.

11. Yeshayahu Y, Sochett EB, Deda L, Sud S, Mahmud FH (2012) Type 1 Diadetes as a Risk Factor for Impaired Vitamin D Status in a Multi-Ethnic Cohort of Canadian Adolescents. Can J Diabetes 36: 314-319.

12. Pozzilli P, Manfrini S, Crino A, Picardi A, Leomanni C, et al. (2005) Low levels of 25-hydroxyvitamin D3 and 1,25-dihydroxyvitamin D3 in patients with newly diagnosed type 1 diabetes. Horm Metab Res 37: 680-683.

13. Norval M (2011) The challenges of UV-induced immunomodulation for children's health. Prog Biophys Mol Biol 107: 323-332. 
Citation: Sonia HL, Ali M, Yousr D, Wiem B, Anies H, et al. (2016) Serum Vitamin D Level in Children with and without Type 1 Diabetes Mellitus. J Diabetes Metab 7: 655. doi:10.4172/2155-6156.1000655

Page 4 of 4

14. Quraishi SA, Camargo CA Jr (2012) Vitamin D in acute stress and critical illness. Curr Opin Clin Nutr Metab Care 15: 625-634.

15. Abrams SA, Coss-Bu JA, Tiosano D (2013) Vitamin D: effects on childhood health and disease. Nat Rev Endocrinol 9: 162-170.

16. Martins D, Wolf M, Pan D, Zadshir A, Tareen N, et al. (2007) Prevalence of cardiovascular risk factors and the serum levels of 25-hydroxyvitamin $D$ in the United States: data from the Third National Health and Nutrition Examination Survey. Arch Intern Med 167: 1159-1165.

17. Thacher TD, Clarke BL (2011) Vitamin D insufficiency. Mayo Clin Proc 86: $50-60$.

18. Poon AH, Mahboub B, Hamid Q (2013) Vitamin D deficiency and severe asthma. Pharmacol Ther 140: 148-155.

19. Ascherio A, Munger KL, Simon KC (2010) Vitamin D and multiple sclerosis Lancet Neurol 9: 599-612.

20. Schoindre Y, Terrier B, Kahn JE, Saadoun D, Souberbielle JC, et al. (2012) Vitamin $\mathrm{D}$ and autoimmunity. Second part: Clinical aspects. Rev Med Interne 33: 87-93.

21. Trump DL, Deeb KK, Johnson CS (2010) Vitamin D: considerations in the continued development as an agent for cancer prevention and therapy. Cancer J 16: 1-9.

22. Holick MF (2007) Vitamin D deficiency. N Engl J Med 357: 266-281.

23. Franchi B, Piazza M, Sandri M, Mazzei F, Maffeis C, et al. (2014) Vitamin D at the onset of type 1 diabetes in Italian children. Eur J Pediatr 173: 477-482.

24. Azab SF, Saleh SH, Elsaeed WF, Abdelsalam SM, Ali AA, et al. (2013) Vitamin $D$ status in diabetic Egyptian children and adolescents: a case-control study. Ital J Pediatr 39: 73.

25. Andadran N, Atelik N, Akaga H, Doayan G (2012) Vitamin D deficiency in children and adolescents. J Clin Res Pediatr Endocrinol 4: 25-29.
26. Rajakumar K, de las Heras J, Chen TC, Lee S, Holick MF, et al. (2011) Vitamin $\mathrm{D}$ status, adiposity, and lipids in black American and Caucasian children. J Clin Endocrinol Metab 96: 1560-1567.

27. Alemzadeh R, Kichler J, Babar G, Calhoun M (2008) Hypovitaminosis D in obese children and adolescents: relationship with adiposity, insulin sensitivity, ethnicity, and season. Metabolism 57: 183-191.

28. Wortsman J, Matsuoka LY, Chen TC, Lu Z, Holick MF (2000) Decreased bioavailability of vitamin $\mathrm{D}$ in obesity. Am J Clin Nutr 72: 690-693.

29. Scragg R, Holdaway I, Singh V, Metcalf P, Baker J, et al. (1995) Serum 25-hydroxyvitamin D3 levels decreased in impaired glucose tolerance and diabetes mellitus. Diabetes Res Clin Pract 27: 181-188.

30. Hypponen E, Power C (2006) Vitamin D status and glucose homeostasis in the 1958 British birth cohort: the role of obesity. Diabetes Care 29: 2244-2246.

31. Gregori S, Giarratana N, Smiroldo S, Uskokovic M, Adorini L (2002) A 1alpha,25-dihydroxyvitamin $\mathrm{D}(3)$ analog enhances regulatory T-cells and arrests autoimmune diabetes in NOD mice. Diabetes 51: 1367-1374.

32. Willheim M, Thien R, Schrattbauer K (1999) Regulatory effects of 1alpha,25dihydroxyvitamin D3 on the cytokine production of human peripheral blood lymphocytes. J Clin Endocrinol Metab 84: 3739:3744.

33. Mathieu C, Waer M, Laureys J, Rutgeerts O, Bouillon R (1994) Prevention of autoimmune diabetes in NOD mice by 1,25 dihydroxyvitamin D3. Diabetologia 37: 552-558.

34. Hypponen E, Laara E, Reunanen A, Jarvelin MR, Virtanen SM (2001) Intake of vitamin $D$ and risk of type 1 diabetes: a birth-cohort study. Lancet 358 : 1500-1503.

35. Aljabri KS, Bokhari SA, Khan MJ (2010) Glycemic changes after vitamin D supplementation in patients with type 1 diabetes mellitus and vitamin D deficiency. Ann Saudi Med 30: 454-458. 